\title{
Validity of Instruments on Knowledge, Attitude and Skills Competencies at SMAN 1 Luhak Nan Duo
}

\author{
Suhelpi ${ }^{1 *}$, Lufri $^{1}$ \\ ${ }^{1}$ Department of Mathematics and Sciences Faculty, Universitas Negeri Padang, Padang, Indonesia \\ *Corresponding author. Email: suhelpi73@gmail.com
}

\begin{abstract}
Learning is activities of teaching, comprehensively refers to the effort of how to make an individual to learn, how to create the learning phenomenon within the individual. Teacher has substantial capabilities to gain success in learning proces, one of them by using proper model of learning with the intention to create effectively and efficiently learning process. Based on the things that abovementioned, research will make a learning modification for the purpose of rectifiying and enchancing the students' competence by using cooperative learning model Team Game Tournament (TGT) type. Concisely, in TGT, the student who has higher capability can cooperate to help another student with lower capability. The TGT model emphasizes on the academic game that aims to make the student happy and gainingthe correct results in learning process.Clasroom Action Research is the chosen methodology for this case, which aims to rectify the teachers' performance in enhancing the students' competencies. The result of validation of this research shows that in knowledge competence validation is $75,00 \%$ valid criteria,behavior competency is $75,00 \%$ valid criteria, and skill competency is $75,00 \%$ valid criteria. As the result, this can be the guidelines to rectify and enchancing the students learning results by using TGT model.
\end{abstract}

\section{Keywords: Team Game Tournament learning model, validity, competency}

\section{INTRODUCTION}

Learn is corollary a changing process of individual which caused by interaction with the environment. After learning people have skills, knowledge, attitudes and values. Thus it can be affirmed that learning is a set of cognitive processes that change the nature of stimulation of the environment, go through information processing and become new capabilities. [1] also added that learning consists of three important components namely external conditions (stimulus from the environment), internal conditions that describe the internal and cognitive conditions of students, and learning outcomes that describe verbal information, intellectual skills, motor skills, attitudes, and cognitive tactics. The wisdom of learning is a change in individual behavior that includes cognitive, affective and psychomotor aspects [2].

[3], states that learning is a learning thing, which means it refers to all attempts at how a person learns and how to produce learning events within that person. In a learning process a teacher is required to have the ability as an educator and teacher. The learning process that researchers have done so far has used several methods equipped with teaching aids such as charta, concept maps and power points but it is still seen that students are not very active and motivated in learning, students wait more and receive explanations from the teacher, and the activities that took place were still teacher centered rather than student centered.

The Team Game Tournament (TGT) is one of the cooperative learning models developed by David DeVries and Keith Edwards, where students play academic games with other team members to contribute points to their team scores [4]. TGT learning can be used for all subjects and is very suitable for teaching with learning objectives that are sharply formulated with one correct answer [5].

Based on the learning that has been going on so far, researchers observe as a teacher at Luhak Nan Duo 1 High School, that the learning carried out has not achieved the expected results. When the teacher delivered the material, many students who paid less attention and tended to talk with their peers, only two to five people asked. In the discussion not all students are involved and tell their friends more, and their activities are very little learning during the learning process. In connection with this, researchers want to make changes to learning to improve and improve the competence of students by using learning models, learning instruments that are complete and according to the needs of students.

To find out whether or not a learning instrument is worthy of an instrument developed on knowledge competencies, attitude competencies, and skills competencies in xi class students. two students must go through several stages of testing, one of which is the 
validity test. Validity is a standard measure that shows the accuracy and validity of the instrument, the test is said to be valid if the test measures what you want to measure [6]. The test has high validity if the results are in accordance with the criteria, in the sense that they have parallels between the test and the criteria. Validity is the ability of a measuring instrument to measure its target size [7]. Validity test is carried out to determine the level of validity of the instruments used. A valid instrument is used to measure what is capable and reveal data from variables that are examined appropriately.

\section{RESEARCH METHODOLOGY}

This type observation is classroom Action Research, the goals are to improve teachers performance, so can enhance student competence. Student competence be expected to change, improvement, quality improvement, change of attitude and skill. This observation is classroom action research referring to spiral model with steps are planning, action, observation and reflection. Instrument validity of competence are knowledge, competence of attitude, competence of skills assessed by validator. But, the researcher just discuss about instrument validity of competence. This observation planned for two cycles, each cycle held with 3 times meeting. This observation as effort to solve all of problems had been faced by the researcher on the field. Validity analysis used validity data practicum guideline that obtained from instrument of data collector based on questionnaire had been filled by expert. Data analysis started with specified scores for each item, validation score specify based on scale Likert by [8]:

\begin{tabular}{ll} 
Score & \multicolumn{1}{c}{ Category } \\
4 & Strongly Agree (SA) \\
3 & Agree (A) \\
2 & Disagree (D) \\
1 & Strongly Disagree (SD)
\end{tabular}

Valuation analysis on instrument competence of knowledge, attitude, and skills based on validity valuation paper with few steps :

a. Score for the answer with criteria based on Likert modified by [8] :

b. Decided the highest score. Highest score $=$ validator total $\mathrm{x}$ indicator total $\mathrm{x}$ maximum score

c. Decided total score with each validator with sum up all the scores that obtained by each indicators.

d. Decided score which is obtained by sum up scores from each validator

e. Validity score with this formula:

Validity Score $=\frac{\text { Total score obtained }}{\text { maximum total score }} \times 100 \%$

Validity score with these criteri:

\begin{tabular}{|c|c|}
\hline Validity Score (\%) & Category \\
\hline $81 \%-100 \%$ & Very Valid \\
\hline
\end{tabular}

\begin{tabular}{|c|c|}
\hline $61 \%-80 \%$ & Valid \\
\hline $41 \%-60 \%$ & Quite Valid \\
\hline $21 \%-40 \%$ & Less Valid \\
\hline $0 \%-20 \%$ & Not Valid \\
\hline
\end{tabular}

\section{RESULTS}

Instruments competence validation of knowledge, attitude, and skill based on instrument validations expert based on steps compilation instruments, so the results instrument competence validation of knowledge, attitude, and skills on the next step validated by experts. [9], validator is just had been done by expert on this field in giving the score to the improved instruments. Validity in this observation is Mr Dr. Ramadhan Sumarmin, M.Si. The validation result instrument competence of knowledge, attitude, and skills can be seen at the appendix.

From results of validation by experts including instrument competence of knowledge, competence of attitude, competence of skills. Validity score on competence of knowledge $75.00 \%$ with valid criteria shows that the guideline and the questions are clearly enough and easy to understand, the questions fulfill the indicator, the lattice questions, and regular layout.

Validation score competence of attitude $75,00 \%$ with criteria valid, shows that aspect had been observed matched with indicator and the goals of education, the guideline and the language matced with EBI, competence score cleary enough, and using types of alphabets are easy to understand and to read. Meanwhile on validation competence of skills $75,00 \%$ with criteria valid, shows that aspect had been observed and formulated matched with the requirements of students and the goals of education, the guideline easy to understand and clear enough, the requirement had been made for rubrics, and using types of alphabet and the meaning of the literature matched with EBI.

The calculation of validaty score with all of the average scores $75,00 \%$ with valid criteria, so the conclusion that instrument competence of knowledge, attitude, and skills can be use as the guideline for push the students more active in learning process, more easier for students to memorized and understand material with model TGT also to improve competence for the students from competence of knowledge, attitude, and skills.

\section{CONCLUSIONS}

Based on observation and discussion, the conclusions are instrument on competence of knowledge, attitude, and skills had been done in the development and improved the competence of knowledge, competence of attitude, and competence skills of students with using TGT model. Instrument can be use for learning process for biology subject. Developed instrument competence has validity valid so the instrument had been developed can be used in learning process to help students in learning activity, to understand problems and to get basic competence for improve the learning competence of students from competence of knowledge, competence of attitude, competence of skills. 


\section{REFERENCES}

[1] Sagala,Syaiful. Konsep dan Makna Pembelajaran.Bandung: Alfabeta. 2014.PP 55-86

[2] [2]Sudjana, Nana. Penilaian Hasil Proses Belajar Mengajar. Bandung:Remaja Rosdakarya. 2010.PP 123

[3] Lufri. Strategi Pembelajaran Biologi. Padang: Universitas Negeri Padang. 2007.PP 70-89

[4] Slavin,E. Cooperative learningTheory,Research and practice Secon Edition, Allyn and Bacon.London;Toronto Sydney Tokyo Singapura,USA. 2005.PP 45-66

[5] Trianto. Mendesain Model Pembelajaran Inovatif Progresif. Jakarta: Kencana. 2010.PP 65-67
[6] Sukardi. Evaluasi Pendidikan Prinsip dan Operasionalnya. Yogyakarta: Bumi Aksara. 2008.PP 12-33

[7] Baswori dan Siskandar. Evaluasi Belajar Berbasis Kinerja. Bandung: Karya Putra Darwati. 2012.PP 6687

[8] Yusuf, M. Metodologi Penelitian. Padang: UNP Press. 2007.pp 23-44

[9] Sari, Rona Taula. Uji Validitas Modul Pembelajaran Biologi Pada Materi Sistem Reproduksi Manusia Melalui Pendekatan Konstruktivisme Untuk Kelas IX SMP. Jurnal Pendidikan Sains. Program Studi Pendidikan Biologi Universitas Bung Hatta. 2017.pp 56-87

\section{Appendix}

THE RESULTS OF ANALYSIS INSTRUMENT COMPETENCE OF KNOWLEDGE, ATTITUDE, AND SKILLS A. Competence of Knowledge

\begin{tabular}{|c|c|c|c|c|c|c|c|c|}
\hline \multirow{2}{*}{ No } & \multirow{2}{*}{ Aspect } & \multicolumn{4}{|c|}{ Score } & Total & $\begin{array}{l}\text { Validity } \\
\text { Score }\end{array}$ & Criteria \\
\hline & & $\mathbf{1}$ & 2 & 3 & 4 & \multirow{13}{*}{36} & \multirow{13}{*}{$\mathbf{7 5 , 0 0 \%}$} & \multirow{13}{*}{ Valid } \\
\hline 1. & $\begin{array}{l}\text { The instructions for filling in the questions } \\
\text { used are written inclearly }\end{array}$ & & & 3 & & & & \\
\hline 2. & The question matched with the indicator. & & & 3 & & & & \\
\hline 3. & $\begin{array}{l}\text { The question matched with the lattice } \\
\text { question. }\end{array}$ & & & 3 & & & & \\
\hline 4. & $\begin{array}{l}\text { The questions matched with the right } \\
\text { concept. }\end{array}$ & & & 3 & & & & \\
\hline 5. & $\begin{array}{l}\text { The subject matter formulated clearlu and } \\
\text { assertive. }\end{array}$ & & & 3 & & & & \\
\hline 6. & $\begin{array}{l}\text { The subject matter not giving the guideline to } \\
\text { the right answer. }\end{array}$ & & & 3 & & & & \\
\hline 7. & The questions have regular words. & & & 3 & & & & \\
\hline 8. & The written scripts are clearly. & & & 3 & & & & \\
\hline 9. & $\begin{array}{l}\text { Using the principle of Indonesia language } \\
\text { with the right rules. }\end{array}$ & & & 3 & & & & \\
\hline 10. & $\begin{array}{l}\text { Using the simple language, straightforward } \\
\text { and doesn't have two value. }\end{array}$ & & & 3 & & & & \\
\hline 11. & $\begin{array}{l}\text { The questions had been made for measuring } \\
\text { students how they understand with the } \\
\text { subjects. }\end{array}$ & & & 3 & & & & \\
\hline 12. & $\begin{array}{l}\text { The total questions are quite enough to } \\
\text { measure how the students understand the } \\
\text { subjects. }\end{array}$ & & & 3 & & & & \\
\hline
\end{tabular}

\begin{tabular}{|c|c|c|c|c|c|c|c|c|}
\hline & & A. & om & ten & of & tude & & \\
\hline \multirow{2}{*}{ No } & \multirow{2}{*}{ Aspect } & \multicolumn{4}{|c|}{ Score } & \multirow{2}{*}{ Total } & \multirow{2}{*}{$\begin{array}{l}\text { Validity } \\
\text { Score }\end{array}$} & \multirow{2}{*}{ Criteria } \\
\hline & & 1 & 2 & 3 & 4 & & & \\
\hline 1. & $\begin{array}{l}\text { The observed aspect matched with the } \\
\text { formulated indicator. }\end{array}$ & & & 3 & & \multirow{4}{*}{27} & \multirow{4}{*}{$75,00 \%$} & \multirow{4}{*}{ Valid } \\
\hline 2. & $\begin{array}{l}\text { The observed aspect matched with the goals } \\
\text { of education. }\end{array}$ & & & 3 & & & & \\
\hline 3. & $\begin{array}{l}\text { The user guideline on observation paper } \\
\text { written with the right language. }\end{array}$ & & & 3 & & & & \\
\hline 4. & $\begin{array}{l}\text { The language for the rubric aspect score of } \\
\text { attitude (observation paper) using the right }\end{array}$ & & & 3 & & & & \\
\hline
\end{tabular}




\begin{tabular}{|l|l|l|l|l|l|l|}
\hline & principle of Bahasa Indonesia. & & & & \\
\hline 5. & $\begin{array}{l}\text { The guideline on paper observation written } \\
\text { with the right sentences. }\end{array}$ & & 3 & & \\
\hline 6. & $\begin{array}{l}\text { The guideline aspect of attitude be included } \\
\text { clearly. }\end{array}$ & & 3 & \\
\hline 7. & The scoring aspect rubric made clearly. & & & 3 & \\
\hline 8. & Observation paper has regular layout. & & & 3 & \\
\hline 9. & $\begin{array}{l}\text { Using of types alphabet and the right font } \\
\text { size. }\end{array}$ & & 3 & & \\
\hline
\end{tabular}

B. Competence of Skills

\begin{tabular}{|c|c|c|c|c|c|c|c|c|}
\hline \multirow{2}{*}{ No } & \multirow{2}{*}{ Aspect } & \multicolumn{4}{|c|}{ Score } & Total & Validity & Criteria \\
\hline & & $\mathbf{1}$ & 2 & 3 & 4 & \multirow{10}{*}{27} & \multirow{10}{*}{$75,00 \%$} & \multirow{10}{*}{ Valid } \\
\hline 1. & $\begin{array}{l}\text { The observed aspect matched with the } \\
\text { formulated indicator. }\end{array}$ & & & 3 & & & & \\
\hline 2. & $\begin{array}{l}\text { The observed aspect matched with the goals } \\
\text { of education. }\end{array}$ & & & 3 & & & & \\
\hline 3. & $\begin{array}{l}\text { The user guideline on observation paper } \\
\text { written with the right language. }\end{array}$ & & & 3 & & & & \\
\hline 4. & $\begin{array}{l}\text { The language for the rubric aspect score of } \\
\text { attitude (observation paper) using the right } \\
\text { principle of Bahasa Indonesia. }\end{array}$ & & & 3 & & & & \\
\hline 5. & $\begin{array}{l}\text { The guideline on paper observation written } \\
\text { with the right sentences. }\end{array}$ & & & 3 & & & & \\
\hline 6. & $\begin{array}{l}\text { The guideline aspect of attitude be included } \\
\text { clearly. }\end{array}$ & & & 3 & & & & \\
\hline 7. & The scoring aspect rubric made clearly. & & & 3 & & & & \\
\hline 8. & Observation paper has regular layout. & & & 3 & & & & \\
\hline 9. & $\begin{array}{l}\text { Using of types alphabet and the right font } \\
\text { size. }\end{array}$ & & & 3 & & & & \\
\hline
\end{tabular}

